\title{
RECOMMENDATIONS FOR INTERVIEWERS CONDUCTING SOCIOLOGICAL SURVEYS: THE USE OF THE PSYCHOTYPES THEORY AND ANALYSIS OF RESPONDENTS' NONVERBAL REACTIONS*
}

\author{
Zh.V. Puzanova, T.I. Larina, S.V. Zakharova \\ Peoples' Friendship University of Russia (RUDN University) \\ Miklukho-Maklaya St., 6, Moscow, 117198, Russia \\ (e-mail: puzanova_zhv@rudn.university, larina_ti@rudn.university, \\ rundmc13@yandex.ru)
}

\begin{abstract}
The quality of sociological data is the problem that cannot lose relevance in the works of methodologists and practicing sociologists for decades. Procedures and techniques for the improvement of the quality of information for all type of survey methods are developing. The purpose of the article is to inform the interviewers conducting semi-structured or unstructured interviews of the recommendations developed on the basis of the theory of psychotypes (by V.V. Ponomarenko). This technology will allow to improve the quality of sociological data. Identification of the psychotype of the respondent and his emotional reactions to different sensitive topics during the interview are the basis of this technology. Emotional reactions can be traced by nonverbal cues (facial expressions, gestures and poses) and interpreted by the technology of the analysis of nonverbal reactions developed and approved earlier. During the multistage experiment, the reactions significant in the course of interview were traced and analyzed - irritation, surprise, sadness, contempt, joy, fear, disgust, stress/discomfort, doubt/indecision, manifestations of mental processes. At the first phase, representatives of 'ideal types' of each psychotype were selected by an abridged psychological test and external diagnostics based on sensitive topics. As a result, the recommendations for a semi-structured interview were formulated. To use this technique, it is necessary to test an interviewee before the interview by the abridged psychological technique (in case there are doubts after the visual diagnostics). According to the psychotype the interviewer pays attention to the sensitive topics of the interview, and during the interview can reformulate the open-ended questions to reduce the sensitivity of significant topics for each respondent.
\end{abstract}

Key words: interview; quality of sociological information; theory of psychotypes; nonverbal reactions; emotions; sensitive topics

While conducting a semi-structured or an unstructured interview a number of opportunities for improving the reliability of the data arise for an interviewer due to reduction of a number of non-respondents and errors in questionnaires. Pithiness and depth of the obtained data are also certain to increase. However, a problem of the representativeness of sociological data, labor input, expenditure, probability of the systematic errors connected to the interviewer's bias arises at the same time.

The quality of the information obtained during the interview depends in many respects on nature of communication, on closeness of interpersonal contact and mutual understanding of the sides. The accuracy of the data in this case directly depends on

* C Zh.V. Puzanova, T.I. Larina, S.V. Zakharova, 2017.

The research was supported by the Russian Foundation for Humanities. Grant № 16-33-00053 (Project "The technology of analysis of respondents' nonverbal reactions in sociological surveys"). 
the quality of the tools developed for the particular research. These, in turn, should meet the following requirements [1]: relevance is "reasons for applicability of the measuring instrument to the measured characteristic"; validity is the situation of "full accordance of cognitive model with the structure of social phenomenon or process under research"; reliability is "the probability of a deviation of the value attributed to an object from its true characteristic"; accuracy is "the amount of gradation of a variable, which can be changed depending on research problems"; stability is "the reproducibility of results in case of repeated samplings". If a tool does not satisfy one of the above-mentioned criteria, it needs to be corrected especially at the design stage or after a pilot study.

It is necessary to emphasize that shifts in the data obtained during a sociological interview are directly caused by the respondents' insincere answers, which, in turn, can be caused by various reasons: from the respondent's incompetence in the matter to the emotional discomfort arising as a reaction of the interviewee to incorrectly formulated questions [2]. The respondent's ability to the correct understanding of the questions and his readiness to give an authentic and intelligible answer is also defined by a series of competence-based, psychological and communicative characteristics of this individual. All these factors can lead to considerable bias of the obtained data, which, in turn, leads to errors during the processing and analysis of the research results. In order to reduce the quantity of such situations the interviewer must create a communicative space, overcome psychological barriers, decrease the respondent's protective reactions and identify their genuine opinions, attitudes, notions, values and so forth [3].

From our point of view, identification of an interviewee's psychotype allows to consider his distinctive features and to apply this information to improve the quality of the obtained data. Features of psychotyping have not been used in sociology due to bulkiness of psychological techniques and procedures and, actually, lack of expediency. However, the science is progressing and new techniques appear, giving researchers a chance to schematize and simplify the diagnosing process. Therefore, for example, the "7 radicals" technique has recently appeared. It allows for rather schematic but quick identification of mental and psychological "orientation", predisposition of the personality in accordance with the offered typology including several main types ('radicals'). The key fact for the interviewer is that each of them has its own features of communication which can be used to create a constructive dialogue with the respondent. On the other hand, this concept is rather versatile and can be used in many social sciences, including sociology.

The author of the technique is V.V. Ponomarenko [4] who believes that the psychotype identified through external characteristics of the person contributes to the understanding of his internal features. This theory focuses on the character of the person, or the individual style of their behavior in social environment, which is formed due to selective assimilation, according to the congenital opportunities, and realization of behavioral stereotypes. The character consists of a set of behavioral patterns, which are seen as homogeneous independent groups of identities (radicals). In other words, the same internal conditions are in the base of each type [4]. The advantage of this theory is the fact that it helps quickly identify the psychotype of a person though observation of the respondent's behavior, their external characteristics (for example, clothes, jewelry, etc.). Respectively, it is possible to divide all people (even if they are very unlike at first 
sight) into certain groups ('psychotype' and 'radical' are synonymous terms within this article, as the sociologist's task is to establish the main, basic radical which determines the whole psychotype). This gives a chance to develop specific recommendations for interviewers on communication with respondents of each psychotype.

The following main psychotypes are defined in the typology of "7 radicals": Hysteroid, Epileptoid, Paranoyal, Emotive, Schizoid, Hyperthim and Alarming. Each of them is presented by the author of the technique according to the following algorithm [4].

- General characteristic: internal conditions, which are the cornerstone origins of the radical and its major social importance.

- The representative's appearance, which includes their constitution, facial expression and gesticulation, which are specific for each radical.

- Qualities of behavior.

- Tasks: which set of tasks is feasible for the concrete radical and which of them are impossible to complete.

- Features of communication: description of the most effective system of interaction with the representative of the specific radical and demonstration of mistakes, which can be made during communication with each radical.

We will give some examples of the description of the main characteristics of radicals.

"Hysteroid": they tend, first of all, to the self-presentation, the main thing for them is to be in the focus of attention, they are inclined to shocking. The speech is melodious, they are very artistic. They like put on fashionably, preferring bright colors. Differ in egoism, are inclined to scandals, skillfully lie, fine manipulators. People at whom this psychotype prevails realize themselves in show business and on television more often.

"Paranoyal": the behavior tendency is to achieve real result of converting activity, they are very purposeful people. The speech is convincing. They are often consider, that the end justifies the means, it is peculiar "revolutionaries", who can throw all forces on realization of the purpose, which they consider important, so other spheres of life, other people suffer because of it. They are also inclined to blackmail. People of this psychotype perfectly realize themselves in policy and as top managers.

"Epileptoid": people who live on a certain order, hate when it is broken. They seek for creation of accurately structured space for life and work in which unforeseen information streams (excess objects and uncontrollable people) are excluded. The speech is distinct. They are constrained, but irritable. These are conservatives, moralizers, but very reliable people. Tend to justice. The man of this psychotype is an officer, the teacher, the doctor.

"Schizoid": People, who create something essentially new. They are inclined to destruction settled technologies of behavior (activity, communications) and to search of original, essentially new; speech is muffled. "Shizoid" is nonplastic, badly feels space, he is not coordinated. This is the person formula. Appearance is often inaccurate because these people sometimes just forget about themselves in the course of considering of the next idea. The thinking is original, but inconsistent. In any sphere of life is an idea man. Intellectuals. Badly feels another. Are inclined to express difficult and vastly simple mentals. He is drawn towards theoretical researches and calculations. They realize themselves in science. 
"Hyperthim": behavior tendency is tendency to elimination of conventions and objectively optional bans in the sphere of communication, to expansion and democratization of a circle of contacts. They have a fluent speech, a loud voice, physical mobility (they are almost not capable to sit long in place). These are very active people to whom it is vital to stay in contact with someone, communication is very important for them, They are frequent the main man in any company. However, they differ in superficiality and lack of attachment to something and to someone. They are recklessly courageous, aren't able to keep foreign secrets. "Hyperthim" is not empathic, but sympathetic. Professions are connected with advertizing, marketing.

"Emotive": always strive for beauty and harmony, for altruism (an example of the person with the dominating emotive-radical - Mother Teresa). In clothes they are prefer muffled tone, have a low melodious voice, without sharp differences. They are capable not only understand, but also to accept any person in ways what he is. They are unprecedentedly kind. They are often realized in the sphere of charity, theater and art in general.

"Alarming": the main tendency of people with this psychotype is fear. They all live after the principle "dangerously" and "as if what it happened". There are no expressed external manifestations. This type seldom meets in a "pure" look, but is very often added to others.

In order to estimate the possibilities of using "7 radicals" technique in sociology, an experiment consisting of several stages was performed. At the first stage, respondents with most expressive radicals were selected as "clean" psychotypes, as the latter does not actually exist in real life. Each person represents a "mixture" of manifestations of different radicals with domination of one or two of them. At the second stage, features of nonverbal behavior of various "clean" psychotypes were traced. We assumed, that emotional manifestations will vary in different experimental groups. As a result, the main aim was to develop recommendations, which will help the interviewer during their work with respondents belonging to different psychotypes easily identified by interviewers.

So, at the first stage the test of Leongard-Shmishek created by Shmishek on the basis of Leongard's classification (he defined his own types taking into account features of character and temperament [5]) was used in order to decrease subjectivity while identifying the psychotype of the respondent. These types formed the basis of the "7 radicals" technique which simplified psychological classification and made it more available for universal using. The test of Shmishek still allows to identify the concrete psychotype, but according to Leongard and our own beliefs this test is used as an additional tool of assessment on an equal basis with external diagnostics where the verbal contact is also included.

In January 2016, we surveyed 100 respondents according to the Leongard-Shmishek questionnaire. The test is rather extensive and consists of 88 questions. Therefore the sub aim of the testing was to reduce the questionnaire through selection of the most sensible and reliable questions. This will give a further chance to use it in the form of a short questionnaire for a respondent before interviewing. Another aim was to reduce the testing time so that not to waste the respondent's time during a real interview, but increase the reliability of the obtained data. As a result, the test was reduced to 21 questions, which had gained the highest coefficients when answered by representatives of "clean" types of each radical. 
The following stage was a semi-structured sensitive interviewing of representatives of "clean" psychotypes in order to identify the behavioral features significant in the context of obtaining sociological data. Sensitive topics were chosen due to the fact, that a respondent shows nonverbal reactions most clearly while discussing these topics (even when they seem to try to hide them). We demonstrated that in other works (for example, see $[2 ; 6])$. It is worth mentioning that only a semi-structured interview was conducted during the research as it sets some formal criteria while giving the interviewer some degree of freedom in providing formulations to respondents (that was important in our experiment). The second stage was aiming at: 1) identifying the dominating emotions and reactions of respondents of different psychotypes during the sensitive interview; 2) revealing topics which are sensitive for each psychotype. When achieved, this aim will allow "to soften" this topic for the specific respondent in advance.

The semi-structured interview was conducted according to the guide including the following blocks of questions: respondent's interests and hobbies; questions concerning political aspects; intimate questions; respondent' daily routine; respondent's private life; questions related to moral values; questions about income. In total 50 interviews with representatives of "clean" psychotypes were conducted and recorded on video. Subsequently nonverbal manifestations of 28 respondents were analyzed by the means of the nonverbal reactions analysis [6]. This technology includes: a) a coding scheme of a respondent's nonverbal reactions; b) nonverbal characteristics of a respondent's probable emotional reactions; c) the description of the emotions influencing quality of sociological information. In total seven basic emotions, and also three unemotional reactions (stress/discomfort, doubt/indecision, mental processes), which were significant in the context of sociological research, are involved in the technology.

1662 nonverbal manifestations ( $80 \%$ - facial expression, $18 \%$ - gestures, $2 \%$ poses) were identified during the interviews; these manifestations compose 432 emotions and non-emotional reactions in total. Such reactions as stress/discomfort $(19 \%)$ were the most widespread, whereas fun/joy/laughter $(1,6 \%)$ were the rarest during the interviews. It is explained by the fact that we deal with the situation of the "sociological" interview during which defense mechanisms are not broken down and lie detection techniques are not applied.

Alarming and Epileptoid respondents became the most active in demonstration of nonverbal manifestations during the semi-structured interview. Respondents of these psychotypes showed the biggest number of emotions (68 emotions and non-emotional reactions) whereas Hysteroids showed the smallest number of emotions.

Representatives of all psychotypes also demonstrated facial expression manifestations. However, this type of nonverbal reactions was shown most often by Epileptoids $(16,4 \%)$. Their most typical manifestation was that of sadness and irritation.

Along with Epileptoids facial expression manifestations were also typical for representatives of Alarming psychotype (15,99\% of manifestations). All psychotypes equally demonstrated specific posture (7) while Alarming respondents used gestures slightly more often than Epileptoids (53 and 44 manifestations respectively).

Respondents of Alarming psychotype showed mental processes (26\% of all emotional reactions of this psychotype) clearly and more often than others as well as displaying stress and discomfort (20\% of manifestations). 
Respondents of Schizoid psychotype are the most reserved in demonstrating nonverbal manifestations according to the results of this research. They displayed facial expressions (165 manifestations) and gesticulated (8,2\% of manifestations) less often than the others and did not react a lot while changing posture during the interview $(9,7 \%)$. Schizoids most often showed surprise (35\%).

Paranoyals did not change their posture when reacting to the questions but gesticulated slightly more often than Schizoids (10,5\% of manifestations). Paranoyals most often displayed manifestations of stress/discomfort (36\% of manifestations) during the interview. They did not demonstrate neither joy/fun, nor fear.

Hysteroids used gesticulation most often in comparison with other psychotypes (19\% of manifestations). Hysteroids showed all emotions and reactions, however irritation $(21,6 \%)$, mental processes, and stress/discomfort were shown most often $(19,6 \%$ for each emotional reaction).

Hyperthims differ about how they changed poses as reactions to the questions slightly more often than other psychotypes (25,8\% of manifestations). Hyperthims manifested indecision/doubt (more than one third) most often with this indicator exceeding several times manifestations of other psychotypes. Hyperthims in the same way as Hysteroids showed all emotions.

Emotive respondents mainly used facial expressions (80\% of manifestations) and gestures (19\% of manifestations) as reaction to the questions. Irritation ( $28 \%$ of manifestations) turned out to be the most widespread reaction among Emotives in the context of this research. They displayed neither disgust, nor joy as reactions to the questions.

Table 1 presents the number of nonverbal manifestations displayed by different psychotypes from the most to the least frequent:

Table 1

The number of emotional reactions of psychotypes

fixed in semi-structured interview

\begin{tabular}{|c|l|c|c|c|c|c|}
\hline $\begin{array}{c}\text { Number of nonverbal } \\
\text { manifestations } \\
\text { from the total } \\
\text { manifistations }\end{array}$ & Psychotypes & $\begin{array}{c}\text { Facial } \\
\text { expression }\end{array}$ & Gestures & Poses & Emotions & $\begin{array}{c}\text { Grade of psychotype } \\
\text { by the number } \\
\text { of emotional } \\
\text { manifestations }\end{array}$ \\
\hline $\mathbf{1 6 , 5 \%}$ & Alarming & 214 & 53 & 7 & $\mathbf{6 8}$ & 1,5 \\
\hline $\mathbf{1 6 , 2} \%$ & Epileptoid & 219 & 44 & 7 & $\mathbf{6 8}$ & 1,5 \\
\hline $\mathbf{1 5 , 2} \%$ & Hysteroid & 192 & 56 & 4 & $\mathbf{5 1}$ & 7 \\
\hline $\mathbf{1 4 , 9 \%}$ & Emotive & 198 & 47 & 2 & $\mathbf{6 0}$ & 5 \\
\hline $\mathbf{1 3 , 1 \%}$ & Hyperthim & 173 & 38 & 8 & $\mathbf{6 4}$ & $\mathbf{6}$ \\
\hline $\mathbf{1 2 , 5 \%}$ & Paranoyal & 177 & 31 & 0 & $\mathbf{6 6}$ & 3 \\
\hline $\mathbf{1 1 , 6 \%}$ & Schizoid & 165 & 24 & 3 & $\mathbf{5 5}$ & 6 \\
\hline
\end{tabular}

According to Table 1, representatives of Schizoid psychotype in the situation of sensitive semi-structured interview show nonverbal manifestations more seldom than the others. However, Hysteroids showed the smallest number of emotions along with other psychotypes despite the large number of nonverbal manifestations. Representatives of Alarming and Epileptoid psychotypes became the most active in demonstrating of various nonverbal manifestations (including emotions).

Table 2 shows that stress/discomfort occupies the first place among other reactions. Fun/joy is on the last place among the displayed reactions. 
Table 3 shows emotions demonstrated as reactions of representatives of various psychotypes to sensitive questions.

In our opinion, blocks 2, 3, 5, 6 are the most significant as they are more sensitive (Table 4). Therefore, the interviewer needs to pay attention to respondent's reactions to these questions. Some recommendations for the interviewers working with sensitive topics are offered below.

Table 2

Rating of emotions displayed during the semi-structured interview

\begin{tabular}{|c|c|l|l|}
\hline Rang & $\begin{array}{c}\text { Number of nonverbal } \\
\text { manifestations }\end{array}$ & \multicolumn{1}{|c|}{$\begin{array}{c}\text { Emotion or non-emotional } \\
\text { reactions }\end{array}$} & \multicolumn{1}{|c|}{$\begin{array}{c}\text { Psychotype which displayed } \\
\text { the emotion most often }\end{array}$} \\
\hline 1 & $19,4 \%$ & Stress, discomfort & Paranoyal \\
\hline 2 & $17,6 \%$ & Mental processes & Alarming \\
\hline 3 & $17,1 \%$ & Irritation & Emotive \\
\hline 4,5 & $11,8 \%$ & Sadness & Epileptoid \\
\hline 4,5 & $11,8 \%$ & Indecision/doubt & Hyperthim \\
\hline 6 & $10,2 \%$ & Surprise & Schizoid \\
\hline 7 & $4,9 \%$ & Contempt & Hyperthim \\
\hline 8 & $3,8 \%$ & Fear & Alarming \\
\hline 9 & $1,8 \%$ & Disgust & Epileptoid \\
\hline 10 & $1,6 \%$ & Fun/joy & Hysteroid \\
\hline
\end{tabular}

Table 3

Emotions and non-emotional reactions shown most often by representatives of various psychotypes during the interview

\begin{tabular}{|l|l|}
\multicolumn{1}{|c|}{ Psychotype } & \multicolumn{1}{c|}{ Emotion } \\
\hline Hysteroid & Irritation \\
\hline Paranoyal & Stress, discomfort \\
\hline Hyperthim & Indecision/doubt \\
\hline Schizoid & Surprise \\
\hline Emotive & Irritation \\
\hline Epileptoid & Irritation, Sadness \\
\hline Alarming & Mental processes \\
\hline
\end{tabular}

Emotional reactions of various psychotypes depending on the question topic

\begin{tabular}{|l|c|c|c|c|c|c|c|}
\hline \multicolumn{1}{|c|}{$\begin{array}{c}\text { Reactions* to various } \\
\text { blocks of questions }\end{array}$} & \multicolumn{5}{c|}{ Psychotype } \\
\cline { 2 - 8 } & Hysteroid & Paranoyal & Hyperthim & Schizoid & Emotive & Epileptoid & Alarming \\
\hline $\begin{array}{l}\text { Block 1 (respondent's } \\
\text { interests and hobbies): } \\
\text { Q. 1-4 }\end{array}$ & 10 & 9 & 9 & 8 & 7 и 8 & 7 и 8 & 8 \\
\hline $\begin{array}{l}\text { Block 2 (political questions): } \\
\text { Q. 5-8 }\end{array}$ & 3 & 9 & 10 & 2 & 3 & 8 (7 и 9) & 8 и 9 \\
\hline $\begin{array}{l}\text { Block 3 (intimate ques- } \\
\text { tions): Q. 11, 12, 23 }\end{array}$ & - & 9 & 10 & 3 & 3 и 9 & 9 & 6 \\
\hline $\begin{array}{l}\text { Block 4 (respondent's daily } \\
\text { routine): Q. 13-15 }\end{array}$ & $8(9)$ & 9 & 8 & 2 & 3 & 9 & 8 \\
\hline $\begin{array}{l}\text { Block 5 (respondent's } \\
\text { private life): Q. 18-22 }\end{array}$ & - & 7 & - & 2 & 8 & 3 & 9 \\
\hline $\begin{array}{l}\text { Block 6 (questions related } \\
\text { to moral values): Q. 9, 10, 24 }\end{array}$ & 9 & 9 и 3 & $3,7,10$ & 8 и 2 & 3 и 9 & 7 & 7 \\
\hline $\begin{array}{l}\text { Block 7 (Questions about } \\
\text { income): Q. 16-17 }\end{array}$ & - & - & 10 & - & 3 & 10 & 9 \\
\hline
\end{tabular}

* interpretation of emotion's coding: 1 - fun/joy; 2 - surprise; 3 - irritation; 4 - contempt; 5 - disgust; 6 fear; 7 - sadness; 8 - mental processes; 9 - stress/discomfort; 10 - indecision/doubt; «一» — the general for most of respondents emotion isn't revealed; (number) - close to an specified indicator. 
It is necessary to approach the Hysteroid psychotype most carefully when asking them questions about politics as this topic causes their irritation while questions related to moral values trigger stress/discomfort. Therefore, it is advisable not to discuss these topics directly, but to try using various polling techniques and methods, which soften wording of the question (for example, projective questions in the first case and abstraction - in the second).

Paranoyals react to intimate questions with sadness and irritation and to questions related to moral values with stress/discomfort. Perhaps, the former is connected with respondent's subjective experiences as well as with their marital status and relations with the partner. Therefore first of all it is necessary to clarify this moment and to continue discussing this topic or to digress to more positive aspects of the interview and return to intimate questions later, depending on the respondent's reaction. The interviewer needs to try to stimulate the respondent to express their own feelings and actions while discussing moral topics by using projective techniques. It is necessary to specify, that questions about sexual minorities have trigged irritation, which can be related to the respondent's religious views or cultural background. The interviewer needs to distance themselves from the respondent by posing impersonal questions or using routinization in the topics, which cause stress / discomfort.

Hyperthims demonstrated ambiguous reaction including irritation and doubt/indecision while answering the block of questions related to moral values. As in the case of Paranoyals it is necessary to take into account cultural and religious background of the respondent while asking them questions about sexual minorities and try to find out his reaction to this topic with precaution. In our opinion, indirect questions could be a good solution as the respondent chooses statements he agrees with. After that, in case of a negative reaction, the interviewer may distance themselves from the respondent using one of the existing techniques. At the same time, representatives of Hyperthim psychotype discuss their daily routine neutrally and these questions cause only manifestations of mental processes.

Representatives of Schizoid psychotype can show inadequate reaction to the occurring situation, therefore any question can be surprising for them. The interviewer should not pay special attention to this fact, because it is not a significant indicator. It is worth mentioning, that intimate questions trigger their irritation. It is caused by the fact that they are reserved by nature and therefore the interviewer should not try to find out too many personal details of their life. It is important to try to avoid discussing this topic or to transfer the discussion from the respondent to another character or a fictional situation (by using distancing, routinization, projective questions).

Emotives treat the sensitive questions with irritation; therefore, it is necessary to try using various polling techniques in order to choose the most effective way of discussing different topics. In our opinion, questions concerning the respondent's immediate circle can be the most useful for finding out the respondent's attitude to this or that phenomenon without asking direct questions. In addition, impersonal forms of questions may work out as well as the respondent will not think that discussion focuses on them. 
Personal questions trigger irritation within Epileptoids, therefore, it is necessary to distance from the respondent by using impersonal forms of questions. Intimate questions cause stress/discomfort, so the interviewer also needs to distance themselves from a concrete situation and use projective questions during this discussion. Questions related to moral values cause sadness, and that is why it is important to lead the discussion in a positive context and use indirect questions so that the respondent could express their position themselves.

Intimate questions trigger fear within Alarming psychotype. Perhaps it is caused by the fact, that they are timid by nature and afraid to share something that other people should not know. We would like to specify that the fear was identified in the answer to a projective question about sexual minorities. It seems logical to say that this emotion is caused by the idea of sudden changes in their life. Thus, it is advisable not to use this type of questions during communication with representatives of Alarming psychotype. Questions related to moral values trigger sadness, so the interviewer needs to use indirect questions while discussing this topic in order to find out the respondent's point of view.

The approach described in this article might seem a mere glass bead game but the authors are convinced that psychodiagnostic testing of a respondent is capable to affect the quality of the obtained data. This statement is valid not only for the interview (semi-structured or unstructured), but for various forms of group discussions, focus groups, etc. It is necessary to add that representatives of all psychotypes benefit from appropriate conditions while being interviewed so that respondents feel more comfortable and are not disturbed by external factors which may cause their negative emotional reactions preventing the obtaining of qualitative sociological information.

\section{REFERENCES}

[1] Batygin G.S. Lektsii po metodologii sotsiologicheskikh issledovanii [Lectures on Methodology of Sociological Research]. Moscow: RUDN; 2008 (In Russ).

[2] Larina T.I. Povyshenie kachestva oprosnogo instrumentariya na osnove analiza neverbalnykh reaktsii respondentov [Improvement of the quality of survey questionnaire on the basis of respondents' nonverbal reactions]: Dissertation. Moscow; 2015 (In Russ).

[3] Zhuravleva I.V. Osobennosti interview kak raznovidnosti metoda oprosa [Features of an interview as survey method]. Andreenkov V.G., Maslova O.M. (Eds.). Metody sbora informatsii v sotsiologicheskikh issledovaniyakh. Moscow: Nauka; 1990 (In Russ).

[4] Ponomarenko V.V. Prakticheskaja harakterologija [Practical Characterology]. Rostov-na-Donu: Feniks; 2006 (In Russ).

[5] Leongard K. Aktsentuirovannye lichnosti [Personality Accentuation]. Kiev: Vysshaya shkola; 1981 (In Russ).

[6] Puzanova Zh.V., Larina T.I. Vozmozhnost analiza neverbalnyh reaktsij respondentov na oprosnyj instrumentarij v pilotazhnyh issledovanijah [Technology of the analysis of respondents' nonverbal reactions to sociological tools in pilot research]. Sotsiologicheskie Issledovaniya. 2017: 2 (In Russ). 


\title{
РЕКОМЕНДАЦИИ ИНТЕРВЬЮЕРАМ ПРИ ПРОВЕДЕНИИ СОЦИОЛОГИЧЕСКИХ ОПРОСОВ: ПРАКТИЧЕСКОЕ ИСПОЛЬЗОВАНИЕ ТЕОРИИ ПСИХОТИПОВ И АНАЛИЗА НЕВЕРБАЛЬНЫХ РЕАКЦИЙ РЕСПОНДЕНТОВ*
}

\author{
Ж.В. Пузанова, Т.И. Ларина, С.В. Захарова \\ Российский университет дружбы народов, \\ ул. Миклухо-Маклая, 6, 117198, Москва, Россия \\ (e-mail: puzanova_zhv@rudn.university, \\ larina_ti@rudn.university, rundmc13@yandex.ru)
}

\begin{abstract}
Качество социологических данных - проблема, не теряющая актуальности в работах методологов и практикующих социологов на протяжении многих десятилетий. Для каждого вида социологического опроса разработаны и продолжают создаваться методики повышения качества данных. Цель статьи - ознакомить с рекомендациями для интервьюеров, использующих полуформализованное или свободное интервью, разработанное на основе теории психотипов (В.В. Пономаренко). Представленная технология работы с использованием этой методики будет способствовать повышению качества социологической информации. В ее основу положены знания о психотипе респондента и его эмоциональных реакциях на сенситивные тематики, демонстрируемые во время интервью. Эмоциональные реакции хорошо прослеживаются на основе невербальных проявлений (мимических, пластических и поз), для анализа которых использована технология анализа невербальных реакций, разработанная и апробированная ранее. В ходе многоэтапного эксперимента отслеживались и анализировались реакции, которые значимы в процессе интервьюирования - раздражение, удивление, печаль, презрение, радость, страх, отвращение, стресс/дискомфорт, сомнение/нерешительность, проявления мыслительных процессов. На первом этапе при помощи сокращенного психологического теста и внешней диагностики были отобраны представители «идеальных типов» каждого психотипа, с которыми было проведено интервью на сензитивные темы. На заключительном этапе была реализован анализ доминирующих реакций, в том числе в зависимости психотипа респондента, и сделаны соответствующие выводы - рекомендации по проведению полуформализованного интервью. Для реализации предложенной техники необходимо перед началом интервью протестировать интервьюируемого по сокращенной психологической методике (если возникли сомнения в ходе визуальной диагностики). В зависимости от психотипа нужно обратить внимание на вопросы по сензитивной тематике, и в случае необходимости по ходу интервью переформулировать вопросы открытого типа так, чтобы снизить сензитивность значимых тем для каждого интервьюируемого.
\end{abstract}

Ключевые слова: интервью; качество социологической информации; теория психотипов; невербальные реакции; эмоции; сензитивные темы

* ( С) Пузанова Ж.В., Ларина Т.И., Захарова С.В., 2017.

Статья подготовлена при поддержке РГНФ. Грант № 16-33-00053 (проект «Технология анализа невербальных реакций респондентов в социологических исследованиях»). 